\title{
MIRA DE AMESCUA, MAESTRO DE CALDERÓN
}

\author{
Juan Manuel Villanueva Fernández \\ UNED
}

\section{Tres CitAs RELEVANTES}

Estamos convencidos de que Arturo Farinelli llevaba toda la razón cuando recomendaba estudiar la producción de Mira de Amescua "che è indubbiamente tra i precursori più geniali ed originali del Calderón» ${ }^{1}$.

Por su parte, Ruth Kennedy, comentando unas ideas de Margaret Wilson sobre la religiosidad y moralidad de Calderón ${ }^{2}$, afirmó:

Estoy de acuerdo con Margaret Wilson en que «la preocupación didáctica [de Calderón] lo enlaza con El Pinciano y con la tragedia moral senequista», pero creo que tanto Mira como Tirso reconocieron que el teatro era «un arte cuyos servicios... podían ponerse a la disposición de la moral y de la religión». Comedias como las piezas de don Álvaro, El condenado por desconfiado, La mujer que manda en casa, y Tanto es lo de más como lo de menos, son sin duda prueba elocuente de la sinceridad de su deseo de hacer del teatro un vehículo para la reforma ${ }^{3}$.

Y, por su cuenta y riesgo, la ilustre hispanista americana recalca con energía el hecho de que Calderón escribió la «Aprobación» de

${ }^{1}$ Farinelli, 1914, p. 325n

2 Estas son las palabras de la ilustre historiadora: «Al elevar su propio status, al reconocerse a sí mismo como un arte cuyos servicios, como los de la pintura, podían ponerse a la disposición de la moral y de la religión, el teatro español aseguró su supervivencia por una generación más... Fue sobre todo él [es decir, Calderón] el que, al aliarse con la frívola comedia, la hizo respetable». Citado en Kennedy, 1983, p. 40.

${ }^{3}$ Kennedy, 1983, p. 40. Y no conviene olvidar que la bilogía de don Álvaro de Luna es de Mira de Amescua; y que El condenado por desconfiado, publicada también en la Segunda Parte de Tirso de Molina, según diversos investigadores, corresponde igualmente al dramaturgo granadino.

Villanueva Fernández, J. M., «Mira de Amescua, maestro de Calderón», en El universo simbólico del poder en el Siglo de Oro, ed. Á. Baraibar y M. Insúa, Nueva York/Pamplona, Instituto de Estudios Auriseculares (IDEA)/Servicio de Publicaciones de la Universidad de Navarra, 2012, pp. 293-314. 
la Quinta parte de Tirso el 16 de julio de 1635, refiriéndose a las «muestras de ciencia, virtud y religión que ha dado Gabriel Téllez a aprehender a los que deseamos imitarle». Y, puesto que no tenemos motivos para dudar de su sinceridad, creemos, con Ruth Lee Kennedy, que «el teatro de Tirso [como el de Mira], fue en varios sentidos un teatro de transición entre el de Lope y el de Calderón»" Después explicaremos por qué añadimos a Mira de Amescua.

\section{UNA OBSERVACIÓN PRELIMINAR}

Antes de comenzar debemos aclarar tres puntos: primero, la fecha de nacimiento de Antonio Mira de Amescua; segundo, la absoluta carencia de justificación científica y literaria del pensamiento que dirigió la publicación de Sociología del teatro del Siglo de Oro, de José Antonio Maravall; y tercero: es inexcusable aclarar que Juana José de Prades nunca afirmó que los personajes del teatro español del Siglo de Oro fueran seis.

\section{Fecha de nacimiento de Mira de Amescua}

La biografia de Mira, en la edición de las Obras completas del accitano, afirma que nació en 1574, consciente de la incoherencia histórica de tal aseveración. ¿Por qué? Los documentos certifican que el presbítero Antonio Mira de Amescua autoriza documentalmente a su padre, en 1593, para que cobre unas comedias. De todos es sabido que el Concilio de Trento estableció la prohibición de ordenar de presbítero a menores de 25 años; y no parece mínimamente serio, mientras no aparezca el documento de dispensa, fijar una fecha que contradice la norma canónica; hipótesis dificultada por la irregularidad en la situación civil y canónica de los padres del joven accitano, en una diócesis ajena a la suya; y, sobre todo, que habrían concedido la dispensa, en el caso de haber nacido en 1574, a un joven de 19 años. Así pues, mientras no aparezca documento en contra, la fecha más tardía, justificable y justificada, para el nacimiento de Antonio Mira de Amescua es el año 1568.

\footnotetext{
${ }^{4}$ Kennedy, 1983, p. 43.
} 


\section{Carencia documental de «Sociología del teatro del Siglo de Oro»}

Con un planteamiento igualmente científico, no puede tomarse en serio un panfleto basado en 30 obras — esas cita el autor- para establecer su pensamiento dogmático; o el de su acólito, José María Díez Borque, cuya relación de piezas justificativas, en su gran mayoría - más de 150-, justifican la teoría contraria. Baste señalar el caso de Los Tellos de Meneses, de la que el estudioso cita la opinión del padre, pero se olvida de la argumentada por el hijo, que es la que constituye la conclusión en la obra.

Incidiendo en esto, Covarrubias, en su Tesoro, contradice radicalmente el caprichoso dogmatismo de Maravall, en la entrada «Fidalgo".

\section{Personajes del teatro del Siglo de Oro}

Las palabras de la ilustre Juana de José Prades, con las que cierra su espléndido ensayo —aparte los «Apéndices»—, son:

Pensamos en la posibilidad de que hallan (sic) escapado a nuestra observación, otros caracteres, otros atributos constantes en los personajes, que puedan ser vistos por investigadores a quienes les interese este tema. El señalamiento de nuevos aspectos preceptivos en los personajes, contribuiría a afirmar la idea fundamental que preside este trabajo. No importa tanto la índole de los caracteres fijos —en las páginas anteriores figuran juntos aspectos físicos, emotivos, psicológicos y éticos- como la certeza de que estos existen.

También, como es natural, damos por cierta la existencia de excepciones, de comedias en las que sea difícil rastrear una convención de personajes y atributos; sobre todo en las obras de índole rigurosamente histórica. Pero ello no es incompatible — creemos—, con la existencia de una convención artística en los personajes de la Comedia Nueva ${ }^{5}$.

Es decir, tratándose de "obras rigurosamente históricas», la admirada estudiosa eliminó cientos — si no, miles- de comedias, a las que no se puede aplicar la archirepetida nómina de los seis personajes.

\footnotetext{
${ }^{5}$ José Prades, 1963, p. 263.
} 
¿POR Qué SON IMPORTANTES LOS TRES PRESUPUestos SEÑAlados?

El primero, porque, habiendo nacido Mira de Amescua en 1568, y habiendo representado dos obras en 1593, parece indiscutible que, en tales comedias y en la formación dramática del guadijano, bajo ningún concepto pudo influir Lope de Vega. Este, por esas fechas, no solo no había establecido su fórmula dramática; antes al contrario, durante su permanencia en Valencia, el Fénix debió de aprender mucho de los autores valencianos. Y, en nuestra opinión, también estaba aprendiendo mucho el joven Mira de Amescua.

En cuanto a la visión sociológica de Maravall, propagada durante muchos años y, por desgracia, todavía conservada en algunos círculos, ha desenfocado esencialmente la lectura de numerosas piezas; sobre todo, por la visión reduccionista de la sociedad española de la época, y la injustificada descripción de la misma, como compartimentos estancos, que dejó sin sentido muchas piezas extraordinarias. Veamos, para confirmarlo, el ejemplo citado de Los Tellos de Meneses:

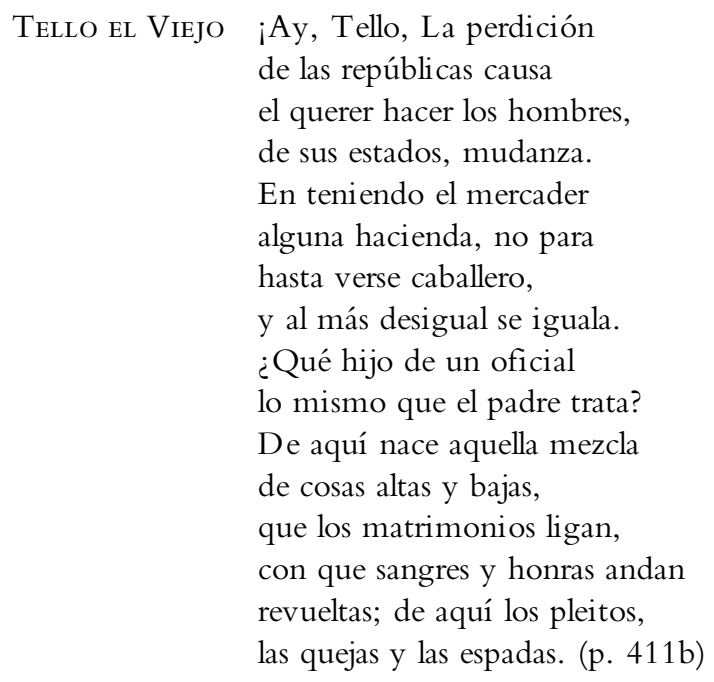

Lo que se le olvidó añadir —o es que ni siquiera lo leyó, lo que sería más triste - es la respuesta del hijo, que, además, es la que se cumple en el final de la acción dramática, arrumbando en el rincón del olvido, por obsoletas, las ideas paternas. He aquí cómo las contradice el vástago: 
Tello el Joven Yo, en efecto, padre mío, no me inclino a cosas bajas: si os cansan mis pensamientos, a mí los vuestros me agravian; que, si vos estáis contento del campo y de su ganancia, yo aspiro a cortes de reyes y a ennoblecer nuestra casa (p. 412a) ${ }^{6}$

Y, por último, la nómina de los personajes del teatro del Siglo de Oro español ha imposibilitado la superación de la taxonomía utilizada por Menéndez Pelayo en sus estudios sobre el teatro de Lope de Vega. Alrededor de esa división temática se siguen dando vueltas y más vueltas que rizan el rizo, pero sin llegar a ninguna parte; aunque alguna aproximación, como las de Marc Vitse e Ignacio Arellano, han desbrozado, con buenas herramientas, el camino hacia el asalto a esa torre todavía infranqueada.

\section{Alcance de la eXPRESIÓN «OBras RIgurosamente históricas»}

Hemos de aclarar un punto fundamental sobre el alcance de la expresión «obras rigurosamente históricas». El hecho de que uno o más personajes hayan tenido realidad histórica no quiere decir que esa pieza sea «rigurosamente histórica»; por poner un ejemplo especialmente relevante, no todas las obras en que intervienen el rey Pedro el Cruel y/o su hermano Enrique son rigurosamente históricas. ¡Ni mucho menos!, esas piezas las concibieron los diferentes dramaturgos con un objetivo determinado, en el que nada tenía que ver la realidad histórica de esos personajes. Así, por ejemplo, en La niña de plata.

Lo mismo cabe decir de buena parte de las comedias consideradas hagiográficas o religiosas, cuyo desarrollo dramático está muy

${ }^{6}$ Sería perder el tiempo entrar siquiera a discutir esta disparatada aseveración: «La sangre que hace nobles hace también virtuosa a la persona, de modo que los poetas dramáticos apoyaron y extendieron la ficción que asimilaba íntimamente la nobleza de alma a la nobleza de sangre», en Díez Borque, 1976, p. 275. Abundan demasiado los nobles traidores y cobardes, así como los valientes en la clase baja. Citar obras como El mejor alcalde, el rey, El testimonio vengado, Los novios de Hornachuelos o El despertar a quien duerme, de Lope de Vega; Las quinas de Portugal y La república al revés, de Tirso de Molina; o La verdad sospechosa, de Ruiz de Alarcón, o... casi ni merece la pena. 
lejos de ser religioso, como expresión particular, o religioso, en general; así sucede con piezas en las que la historicidad se limita a la intervención del santo o la devoción correspondiente; pero que, en su desarrollo, se trata de una comedia más, pues el argumento al que se alude en el título, apenas si ocupa algún centenar de versos al final de la acción.

Ahora bien, el alcance del término «historicidad» aplicado al teatro áureo español tampoco se corresponde con el actual. De ahí que, para comprender mejor el conjunto de «obras rigurosamente históricas», identificaremos como tales las piezas inspiradas en documentos escritos históricos o, en su caso, en tradiciones bien asentadas en la sociedad; por eso, por ejemplo, en el caso de las comedias inspiradas en la Sagrada Escritura, incluimos las que desarrollan algún episodio de los Evangelios Apócrifos. Y, en el caso de la historia profana, incluiremos aquellas de personajes históricos, pero en las que, por el objetivo perseguido por el autor, no se circunscribe a los hechos, sino que introduce elementos anacrónicos que ayudan a desarrollar con más claridad el objetivo perseguido. Es el caso tanto de La rueda de la Fortuna como de La gran Cenobia.

Antonio Mira de Amescua, creador de dos obras seminales del Siglo de Oro

Fue el gran hispanista Alexander A. Parker quien afirmó que El esclavo del demonio era una de las obras seminales del Siglo de Oro español, de la que aprendieron prácticamente el resto de autores que dramatizaron las vidas contrastadas de buenos o/y hasta ejemplares personajes cristianos que, tras haber caído en una tentación, se dedicaron al bandolerismo.

Lo mismo cabe decir, acaso más, de La rueda de la Fortuna, aprovechada en distintas ocasiones por Tirso de Molina, Calderón de la Barca e, incluso, el propio Fénix de los Ingenios.

Ruth Lee Kennedy, que tan bien conocía a Tirso de Molina, hablando de un tipo de silva, no dudó en afirmar:

Los estudios que yo misma he hecho de esta estrofa y de su empleo (que reconozco están lejos de ser completos) me llevan a creer que nació en 1621, aunque no puedo decir si fue Tirso o Mira quien la originó. El primero la emplea en El árbol del mejor fruto (I, 1), que es casi seguro existía ya por el 3 de mayo de 1621, pero hay indicaciones de que en es- 
te tiempo Tirso está siguiendo los manuscritos de Mira casi al paso que iban saliendo de su pluma ${ }^{7}$.

Resultaría asombroso a la mayoría de los presentes, supongo, comprobar los investigadores y máximas alabanzas sobre diferentes piezas del dramaturgo granadino; eso sí, individualizadas en obras distintas. Sin embargo, Mira sigue contabilizado entre los autores de segunda línea. ¿Por qué?

Lo atribuimos al juicio emitido por Cotarelo - que no entendió ninguna de las grandes obras del accitano-, hace ya casi cien años, y que, frente a la facilidad con que justifica los convencionalismos áureos —incluyendo, naturalmente, los anacronismos- en los demás autores —entre ellos, por supuesto, Calderón-, con el mayor desparpajo-cinismo afirmó sobre La rueda de la Fortuna:

Comienza por una gran inverosimilitud, cual es suponer que la emperatriz Aureliana oculta su hijo legítimo en una aldea y le sustituye en palacio con el hijo de una esclava, que disfruta todos los honores de Príncipe heredero. Su mismo marido lo ignora y no se adivina la causa fundada de la ocultación, pues Mauricio, emperador, es viejo y nada hace temer que el Príncipe corra peligro alguno.

Otro de los episodios, no ya inverosímil sino ridículo de puro extravagante, es el del águila que arroja en el campo de los sublevados una espada, que da el trono al pastor Focas, pues ninguno más que él puede desenvainarla; en una comedia de magia podría pasar.

Al morir el emperador Mauricio reconoce por hijo suyo a Heraclio, que no lo fue sino de otro Heraclio de Cartago y Mauricio era de Capadocia.

Huelga insistir sobre "las arquitecturas del ingenio fingidas», de Tirso; recalquemos, eso sí, que, con semejante disparatado fundamento crítico, debemos condenar al ostracismo obras como Edipo rey, Macbeth o La vida es sueño. No obstante, en el caso del accitano, los críticos reiteran la susodicha crítica, imposibilitándole el calificativo que merece: obra maestra. Y esto, a pesar de que, aparte de lo

${ }^{7}$ Kennedy, 1981, p. 238. En cuanto al comentario de la estudiosa tirsista, sobre la «silva», señalaremos que, en los versos 1859 y siguientes de nuestra edición de Examinarse a ser rey —así es como se titula en el manuscrito de la Biblioteca Nacional de Madrid-, la mala administración de justicia del Infante se desarrolla en esa estrofa; y la obra pertenece a una fecha anterior a 1621. 
publicado sobre la historicidad y los anacronismos en el teatro áureo por distintos autores, Ignacio Arellano ha escrito de forma tajante, definitiva e irreprochable: «No tiene sentido, por tanto, enfocar el análisis de un drama histórico desde la perspectiva de la objetividad histórica. El poeta siempre pretende otra cosa. Qué sea lo que pretende variará en cada caso» ${ }^{8}$.

¡Aquí está la madre del cordero!, diríamos con expresión popular. Cegados por la apariencia de unos hechos anacrónicos, los árboles no han dejado ver el bosque, y los críticos han olvidado la perspectiva dramática y teológica que constituye la esencia, la razón de ser de esta excepcional obra. Porque, en La Rueda de la Fortuna, Mira de Amescua plantea el problema teológico del regicidiotiranicidio9. Pero, de manera similar a cómo había dramatizada, en

${ }^{8}$ Arellano, 2001, p. 570.

${ }^{9}$ La mayor parte, si no la unanimidad de los estudiosos, han interpretado este hecho como un problema jurídico, lo que lleva necesariamente a una interpretación de la obra como una "comedia heroica»; sin embargo, la realidad es muy distinta. En la época que estudiamos, el teatro áureo, estos problemas eran mucho más que un problema jurídico; era una cuestión teológica. En línea con el planteamiento de Francisco de Vitoria, y las discusiones con los juristas de la corte del emperador Carlos V, el ilustre dominico repitió sin cansarse que él solo hacía teología; y que precisamente por dedicarse a la teología, debía entrar en el análisis de los problemas de la conquista - y cuestiones derivadas- del Nuevo Mundo. Inmensa fue la repercusión de las «Relectiones» de Francisco de Vitoria, hasta el punto de que fundamentaron la redacción de las Nuevas leyes de Indias (1542), frente a las de 1512. Lo mismo cabe decir del tema del tiranicidio, enunciado con toda su crudeza por el padre Mariana, en De rege (1600), a la que se atribuyó la responsabilidad teórica del regicidio de Enrique IV, de Francia, (1610), y la subsiguiente condena, quema del libro, y prohibición de defender, en las aulas universitarias, el regicidio. No podemos, por supuesto, introducirnos en el desarrollo de estos hechos; pero parece indudable que olvidar este planteamiento teológico, con los argumentos explicitados sobre la legitimidad de acabar con la vida del tirano en ciertas ocasiones, es negarnos a reconocer en toda su extensión y grandeza las dramatizaciones llevadas a las tablas por nuestros mayores autores. Al fin y al cabo, como decía Vitoria en sus reflexiones teológicas, tras el problema político, hay otro teológico-moral que solo puede resolverse, por afectar a la conciencia cristiana, con ayuda de la teología. Villanueva, 2001, pp. 33-38. Ya Nicolás González Ruiz, 1946, 8`, proclamó: «En toda obra fundamental de teatro hay una comedia teológica en potencia. Pero no tenemos derecho a incluir en este grupo sino las comedias que deliberadamente se escribieron con el fin de plantear y resolver un problema teológico ante el espectador». Esta vertiente ha sido soslayada por los estudiosos; pero será necesario retomarla si queremos entender correctamente nuestro teatro áureo. 
El esclavo del demonio, el tema de la gracia ${ }^{10}$, no se conforma con una mera dramatización de un regicidio-tiranicidio; plantea, más bien, el problema complejo del regicidio, con una perspectiva múltiple, respecto a la legalidad-legitimidad de matar a un rey. Es decir, dramatiza, soslayando reflexiones y silogismos filosóficos y teológicos - que reserva para los manuales de filosofia, derecho y teología- y los convierte en sangre de diálogos pletóricos de vida teatral, diversas perspectivas del problema: la muerte de un rey legítimo convertido en tirano, la de un tirano que mata al emperador legítimo, y la de un príncipe -que, al final, resulta no ser el verdadero hijo del emperador-que es mal hijo y príncipe prepotente e inmoral.

\section{Mira de Amescua, maestro de Calderón}

En su espléndido discurso de entrada en la Real Academia Española, José Alcalá Zamora apuntó «tres influjos tempranos» en la formación literaria de Calderón: primero, «el mundo mágico, maravilloso del nuevo teatro, donde cualquier sueño puede hacerse realidad durante unas horas»; segundo, «el nuevo estilo lírico de Góngora»; y tercero, "el fascinante y amargo mundo del Quijote» ${ }^{11}$. Con otras palabras, el ilustre académico viene a defender implícitamente que la fórmula dramática calderoniana fue exclusivo mérito del ingenio del madrileño. Afirmación muy discutible — que recuerda la época, por suerte ya periclitada, en la que se consideraba a Lope, creador único y absoluto de la comedia nacional-, pues las cosas no son tan simples si creemos al propio Calderón, en su «Aprobación» de la Quinta parte de Tirso, con cuya cita iniciábamos estas páginas, al tiempo que retrasábamos la justificación de añadir a Mira de Amescua.

Veamos los «tres influjos tempranos» señalados por José Alcalá Zamora:

Primero: siempre que se hable de la comedia del Siglo de Oro, por supuesto, debemos tener presente a Lope de Vega. Ahora bien, cuando hablamos de las diferencias - prácticamente reconocidas por todos los estudiosos - del teatro de Calderón respecto al del Fénix, nos vemos obligados a buscar otras fuentes de inspiración; y

${ }^{10}$ Villanueva, 2001, pp. 337-373.

${ }^{11}$ Alcalá Zamora, 2001, p. 537. 
así, aprovechando trabajos de nuestros predecesores, más los nuestros, podemos apuntar:

1. Valbuena Prat demostró hasta la saciedad la influencia directa de El esclavo del demonio, del dramaturgo accitano, sobre El mágico prodigioso y La devoción de la cruz, así como en varios autos sacramentales.

2. Personalmente, en un estudio sobre En esta vida todo es verdad y todo es mentira, hemos demostrado que, además de La rueda de la Fortuna, Calderón utilizó, para la redacción de su importante comedia, otra del accitano: Examinarse a ser rey ${ }^{12}$.

3. Entre las obras primerizas del autor de La vida es sueño, se cuenta El alcalde de sí mismo, obra en la que sigue, tanto en la planificación como en buena parte del desarrollo dramático, Callar en buena ocasión o Vivo muerto y enterrado, así como la citada de Examinarse a ser rey.

Segundo: «El nuevo estilo lírico de Góngora». Aunque, tal vez, la influencia mayor del estilo "gongorino» de Calderón aparezca en los años posteriores, diversos estudios de Gregg, Herrero, Tyler, Williamsen, Rodríguez Adrados y Cigüeña Beccaría, entre otros, han demostrado cómo Calderón asimiló y utilizó directamente diversos datos y recursos específicos, si no exclusivos, de Mira de Amescua. Ya Mesonero Romanos exaltó como un gran mérito del teatro del accitano: «trozos y escenas llenos de pasión, de verdad y de fuerza cómica», y alabó «el ingenioso artificio, la brillantez de su forma, y aquel énfasis de dicción que entonces estaba tan en boga, y del que seguramente se dejó arrastrar algo más de lo que debiera». En línea con esta alabanza, $M^{a}$ Dolores Cigüeña estudia el siguiente fragmento de Hero y Leandro, vv. 295-314:

Hero El osado pecho ofrece, al agua, desde una roca, $y$, con la espada en la boca, delfin humano parece; ¡tiradle flechas y muera, sobre las ondas de nieve, hombre que a ofender se atreve deidad que Chipre venera! ¿Qué marino, monstruo o nave

${ }^{12}$ Villanueva, 2004. 


\author{
no va excediendo esta vez? \\ Lo que moja el agua es pez, \\ lo que toca el aire es ave, \\ rompiendo va en las espumas \\ grillos de ovas y de lamas \\ el medio cuerpo de escamas, \\ y el otro medio de plumas. \\ Grande valor has mostrado, \\ parece en el mar cruel \\ fragmento de algún bajel \\ que el viento ha despedazado.
}

Y afirma:

Mira de Amescua es capaz de condensar en estos veinte versos una sucesión de imágenes brillantes y sugestivas, que configuran una atmósfera de enorme movimiento, de cambio constante, de esforzada lucha del hombre contra los elementos, imágenes que, por todo ello, cautivarán inevitablemente a Calderón. Así, Leandro es sucesiva y simultáneamente un delfín humano, una nave o un bajel, y un nuevo monstruo marino. De todas las imágenes que aquí se suceden, probablemente, la más sobresaliente sea la de esa simbiosis de pez y ave que presente a Leandro como un quimérico animal cubierto a la vez de escamas y plumas ${ }^{13}$.

Y señala la aplicación en doce piezas calderonianas.

Y tercero: «el fascinante y amargo mundo del Quijote, donde Miguel de Cervantes, otro rebelde distinto, escapa por las soledades y campos de La Mancha de una realidad que no puede modificar y contra la que se embotan, con burla y tristeza, los golpes generosos del más célebre de los héroes caballerescos» (p. 537).

La respuesta a esta aseveración justifica este trabajo, a partir de, en primer lugar, lo que representó, en la producción dramática de Calderón, La gran Cenobia; así como, en segundo lugar, las grandes conexiones que esta obra primeriza tiene con La rueda de la Fortuna, de Mira de Amescua, especialmente en el análisis de los principios y obligaciones derivados de ostentar el poder.

En cuanto a la primera aseveración, la importancia de La gran Cenobia en el teatro calderoniano, cedemos la palabra directamente al propio Alcalá-Zamora:

${ }^{13}$ Cigüeña, 1989, pp. 469-470. 
No por ser de las mejores, aunque el vigoroso aliento dramático de la segunda merezca esa nota, sino por responder de una forma más directa al objetivo que me propongo, destacaré dos de ellas, Amor, Honor y Poder y La gran Cenobia, o más propiamente, tragedia de Aureliano. Ambas giran en torno al tema político del abuso de poder y de la tiranía y en ambas están ya las ideas básicas, inquietudes e interrogaciones que desarrollará el escritor durante el largo itinerario de su producción teatral ${ }^{14}$.

Matizaremos que no es «tema político», sino, sobre todo, «teológico».

Pasemos, pues, a la segunda cuestión, partiendo igualmente del mismo discurso del ilustre académico. Hallamos dos fragmentos especialmente representativos ${ }^{15}$ : el primero explicaría la elección del tema por parte del dramaturgo; mientras que el segundo demostraría que Calderón coincidía, con unos autores, a la vez que disentiría de otros, en su postura frente al regicidio o tiranicidio; pero que, en el fundamento, desarrollo y conclusión dramáticos, solo intervino su capacidad creadora ${ }^{16}$.

He aquí los fragmentos:

1) La reflexión sobre el poder y la política y las relaciones entre gobernantes y gobernados, esa reflexión que con preguntas primordiales discurrirá por toda la longitud de la obra dramática calderoniana en busca de la respuesta que solo al final, me parece, pensó haber encontrado. Los estímulos, experiencias y conocimientos que acumulara durante la segunda mitad del reinado de Felipe III hubieron de condicionar su profundo y

${ }^{14}$ Alcalá-Zamora, p. 540.

${ }^{15}$ Hay un tercero, que también está relacionado con el tema que nos ocupa, pero sus conexiones, arraigadas en la tragedia griega euripidea, nos exigirían una extensión de que hoy no disponemos [Villanueva, 2001, pp. 221 y ss.]; nos referimos al "Amor a la vida» - no hay cosa como vivir (Antes que todo es mi dama)—, de la que también corresponde a Mira de Amescua la dramatización plena, en su interrelación política respecto al poder y el gobierno, con esa pieza bastante olvidada titulada No hay reinar como vivir, que incluye la defensa y la crítica, respectivamente de los traidores y los fieles, respecto a justificar la traición por reinar.

${ }^{16}$ Algo similar deberíamos decir respecto al, por múltiples causas, espléndido libro de Antonio Regalado sobre la modernidad de Calderón, en el que tanta importancia tiene En esta vida todo es verdad y todo mentira; pero debemos conformarnos, al menos por hoy, con lo ya señalado sobre su dependencia de dos piezas amescuanas: La meda de la Fortuna y Examinarse de rey. 
duradero interés hacia el tema; pensamientos que, con el enfrentamiento que tuvo con distintos poderes - padre, Ratio Studiorum y sus conocimientos de Derecho Natural, Político y Administrativo-, condujo sus inquietudes con mayor matiz y suficiencia hacia el tema de los gobernantes y del Estado, considerando a este en principio opuesto y en parte incompatible, al menos amenazador, respecto a la dignidad, u honor, proyectos y libertades del individuo (p. 539).

2) Calderón de la Barca, tan sensibilizado en el punto de los excesos de autoridad y al tanto del tratamiento del asunto por los comediógrafos del ciclo de Lope, lo aborda con valiente decisión desde sus primeros estrenos. En obsequio de la brevedad, prescindo de acudir al padre Mariana y a otros estudiosos del problema y me limitaré a recordar las posiciones antagónicas de Guillén de Castro y Tirso de Molina, uno y otro en la cumbre de su prestigio. La línea ideológica de aquél, objeto de valiosos estudios recientes en cuya prolongación se sitúa Cenobia, indaga los límites de las facultades del soberano y defiende frente a él los derechos y justas expectativas de los súbditos, dentro de la tradicional doctrina pactista. Por lo que se refiere al mercedario, en una comedia muy sugerente, La república al revés, donde comenta el tópico, tan entrañablemente barroco, de la Rueda de la Fortuna, establece una frontera política incompatible con las tesis del valenciano:

$$
\begin{aligned}
& \text { No hay ley } \\
& \text { con que despoje un vasallo } \\
& \text {-ni razón ninguna hallo-, } \\
& \text { por malo que sea, a su rey. (III) }
\end{aligned}
$$

Este segundo fragmento es, sin duda, uno de los más, si no el más, desafortunado del discurso, pues podríamos afirmar, con expresión coloquial, que "no dio ni una». En primer lugar, prescinde del padre Mariana, lo cual representa la plena incapacidad comprensiva del resto. Y, en segundo lugar, a la hora de inclinar la balanza en la dirección de Guillén o de Tirso, se decide por el valenciano, porque Cenobia es una prolongación de su ideología, mientras que la del mercedario sería incompatible. Pero, ¿esto es así? Vayamos por partes.

¿Qué se pretende, en realidad, con La gran Cenobia? Calderón dramatiza los abusos de un tirano emperador - elegido por aclamación del ejército-, que culminarán — tras una injusta e inmoral administración de justicia_ - en su muerte — tiranicidio-, y el regi- 
cidio de un rey legítimo y bueno - esposo de Cenobia, del que se habla, pero no interviene en la acción-, cuyos asesinos serán condenados a muerte por el siguiente emperador aclamado inmediatamente después de haber matado personalmente al tirano ${ }^{17}$.

Este axioma ("Regno ergo sum», adaptación según Leibniz, derivada del "cogito ergo sum» cartesiano) es afin al que la desesperada Semíramis enuncia negativamente («sin ser estoy, supuesto que no reino»).

Un cuarto de siglo antes de que se escucharan en los teatros de Madrid estas palabras, el joven dramaturgo había afinado ya la puntería cuando puso en escena la ambición de Aureliano en La gran Cenobia (1625). En la primera escena de la obra, Aureliano representa, en la soledad de un bosque, la voluntad de poder que define primordialmente como una maestría sobre sí mismo, un absoluto mandarse a sí mismo: Pequeño mundo soy, y en esto fundo / que, en ser señor de mí, lo soy del mundo ${ }^{18}$.

Puesto que analizamos las conexiones e interrelaciones de esta obra con El amor constante y El perfecto caballero, de Guillén de Castro, o con La república al revés, de Tirso de Molina, hemos de decir que, entre los autores citados, sin duda alguna, abundan más las conexiones con la obra de Tirso.

${ }^{17}$ José Alcalá-Zamora y Queipo de Llano escribe: «La segunda edición, 1673, del auto La vida es sueño, aborda los puntos expuestos desde el enfoque teológico, relacionándolos con la persona del Dios trino: "del Poder criados y de la ciencia instruidos y adornados del amor", idea que reitera el 20 de mayo de 1681 en su testamento, donde se refiere al amor que conduce al "verdadero conocimiento". Y surge aquí una pregunta que concierne al concepto mismo de auto sacramental: ¿es la especulación teológica la que influye en la reflexión secular o, por el contrario, son las experiencias e inquietudes humanísticas y políticas las que inducen el sentido de aquellas?» (p. 563). Es como si, a pesar de la evidencia de los autos sacramentales y de algunas comedias teológicas, en cuya relación no podemos ni debemos entrar, pretendiéramos olvidar que Calderón era maestro en las dos teologías - escolástica y positiva-, y que ese conocimiento lo trasladó a su teatro; pero no se trata de que lo llevara a su teatro. Dio múltiples muestras, en su vida, de la sinceridad de su fe... No podemos entrar en la discusión de fe, teatro y vida...

${ }^{18}$ Regalado, pp. 889-890. Ahora bien, otros cinco lustros antes, en Las desgracias del rey don Alfonso el Casto, de Mira, Ancelino, ante la muerte de Mauregato, decide también reinar, aunque sea solo un día; también en El primer conde de Flandes y, repitámoslo, en La rueda de la Fortuna. 
En el caso de El amor constante, de Guillén, el tiranicidio se limita esencialmente a vengar la muerte de unos padres, con la explícita autorización -el homicida se autocondena inconscientemente, pues cae en la trampa que le tiende el joven regicida- del rey tirano. La concepción del tiranicidio, con planteamiento moral, no está suficientemente clara; de hecho, los investigadores están divididos entre los que hablan de tiranicidio y los que sostienen que se trata de un simple tema dramático.

Con La república al revés no sucede lo mismo; pero, ¿y los versos citados? Están en la obra y, sí, es cierto, los pronuncia la reina (madre); pero, ¡cuidado!, están dirigidos al traidor Leoncio, que se ha autonombrado «emperador, aunque sea por un solo día» - ¿no suena esto a Focas, de La rueda de la Fortuna?-; más aún, si observamos bien los versos, nada tienen que ver con el tiranicidio; su significado real, y el único posible en La república, es el de haber despojado del reino a Constantino, sin corresponder su actuación al tema del tiranicidio en sentido estricto. No obstante, en esta pieza sí hay verdadero tiranicidio - aunque se limite a la ceguera, la condena del rey es total, y su apartamiento del trono, definitivo, resultando baldías las súplicas de la reina-esposa, deseosa de perdonar al tirano. De ahí que, en realidad, contrastando los resúmenes, se evidencia que las más directas y abundantes conexiones las tiene con La rueda de la Fortuna, del granadino.

Buena parte del camino hacia Mira de Amescua lo abrió Ruth Lee Kennedy, con un artículo bastante olvidado por los investigadores que, por lo mismo, andan un tanto despistados en cuanto a las verdaderas raíces del pensamiento sobre el poder en el teatro de Tirso de Molina ${ }^{19}$. Pero creemos que se trata de un estudio definitivo, en cuanto a las tremendas deudas del madrileño con La rueda..., en la obra que nos ocupa... y en otras.

¿Y el padre Mariana? Desde la perspectiva de nuestro tiempo, el tema del tiranicidio se considera propio de los estudios jurídicos. Sin embargo, en la época que nos ocupa, era un tema, como el de la «educación de príncipes», que pertenecía a la teología exclusivamente desde sus orígenes. En este sentido, hemos de proclamar que nos hallamos ante una obra teológica, en la que tienen mucha importancia las cuestiones teológicas de la educación del príncipe; así

${ }^{19}$ Kennedy, 1972, 1973a, 1973b, 1980; sobre todo, 1973 a. 
lo hallamos en el comienzo de La república al revés, cuando la reina Irene entrega el reino — por medio de sus símbolos- a su hijo; como, en La rueda de la Fortuna, el emperador Mauricio, agonizante, declara las pautas del buen rey, en el momento de la agnición, a su hijo Heraclio.

Por último, en La gran Cenobia, Calderón, para dramatizar otra injusta actuación del tirano, aprovecha un recurso inventado por Mira de Amescua, el de las "voces del cielo», utilizado en sus primeras comedias ${ }^{20}$, e imitado también por Tirso de Molina y Diamante. Calderón lo usa en La gran Cenobia, en las escenas siguientes al momento en que Aureliano arroja - entierra viva - a Astrea en una cueva profunda. Las quejas y lamentaciones de esta son «voces del cielo", en el sentido amescuano, para Cenobia, Libio y Decio, quien, finalmente, la libera de su encierro. Calderón pudo aprender el recurso de El esclavo del demonio; pero, por la escena y su desarrollo, el paralelismo más próximo lo tiene con Las lises de Francia, si bien ignoramos cómo pudo conocerla el autor de La gran Cenobia.

Citemos, para terminar, un fragmento de Cenobia, en el que dialogan Aureliano y Decio; importa recalcar que viene a ser un resumen de los diálogos entre los generales Filipo y Leoncio, de La rueda de la Fortuna, incluyendo algún verso literal del accitano.

Aureliano Cobarde, a mí?

¿Puedo ser vencido yo?

¿Puedo yo mudanza alguna

padecer en tanto honor?

Di, ¿tiene el tiempo valor?

¿Tiene poder la fortuna?

¿Hay en la suerte importuna

causa, que incite mis daños?

Decio Sí; que hay en el tiempo engaños, hay en la suerte venganzas, en la fortuna mudanzas, $\mathrm{y}$, en mi vida desengaños.

Tú eras ayer un soldado, y hoy tienes cetro real; yo era ayer un general, y hoy soy un hombre afrentado;

${ }^{20}$ Villanueva, 2001, pp. 227-233; incluye bibliografia. 
tú has subido, y yo he bajado: y, pues yo bajo, advirtiendo sube, Aureliano, y temiendo el día que ha de venir; pues has hallado, al subir, otro que viene cayendo. Los dos extremos seremos de la fortuna y la suerte; mas ya en la mía se advierte el mayor de los extremos; que, si en la fortuna vemos que no es hoy lo que era ayer, yo no tengo que temer, y tú tienes que sentir, pues bajo para subir, pues subes para caer. Tan confiado no estés, pues no estoy desconfiado; que puede ser que el estado trueque la suerte que ves, y que tú, puesto a mis pies, por decretos soberanos, des venganza a los tiranos pechos ${ }^{21}$.

\section{SÉNECA Y LA TRAGEDIA MORATA}

Retomamos la cita de Margaret Wilson, traída al comienzo de estas páginas, sobre el senequismo y el Pinciano, y aprovechamos la ocasión para recordar que Fausta Antonucci, en el último artículo que conocemos sobre La gran Cenobia, afirma:

Parece evidente que Calderón, al componer obras como El sitio de Bredá, y aún más Judas Macabeo y La gran Cenobia [las tres, en nuestra opinión, influidas por Mira de Amescua], que tratan de historia antigua y agitan importantes temáticas políticas y morales, tenía muy presente el modelo de la tragedia renacentista declinado en su moralidad morata ${ }^{22}$.

Suele repetirse con frecuencia que la tragedia senequista desaparece en España con los trágicos valencianos; sin embargo, las cosas

${ }^{21}$ Calderón de la Barca: La gran Cenobia, p. 75b.

22 Antonucci, 2011, p. 141. 
no son exactamente así, como hemos demostrado desde hace muchos años. Pero, para nuestro interés de hoy, bastará recordar que, respecto a La rueda de la Fortuna ${ }^{23}$, hace más de dos décadas que la calificamos de tragedia morata; por lo que, de acuerdo con lo señalado, a Calderón le bastaba seguir las directrices del dramaturgo accitano para dotar a La gran Cenobia de los rasgos que recordaban la tragedia senequista y la finalidad docente de la morata; por supuesto, docencia teológica, de cuyo dominio escolástico y positivo dejaron testimonio buenos estudiosos de su teatro.

\section{Bibliografía}

Alcalá-Zamora, J., La reflexión política en el itinerario del teatro calderoniano. Discurso de ingreso en la Real Academia de la Historia. Utilizamos la edición recogida en La teatralización de la historia en el Siglo de Oro Español. Actas del III Coloquio del Aula Biblioteca "Mira de Amescua» celebrado en Granada del 5 al 7 de noviembre de 1999 y cuatro estudios clásicos sobre el tema, ed. R. Castilla y M. González Denigra, Granada, Universidad, 2001, pp. 529568.

Antonucci, F., «Las emociones trágicas y el paradigma de la tragedia en el teatro del joven Calderón: unas calas», en Emocionar escribiendo. Teatralidad y géneros literarios en la España áurea. ed. L. Gentilli y R. Londero, Madrid/Frankfurt, Iberoamericana/Vervuert, 2011, pp. 129-145.

Arellano, I., «Poesía, historia, mito en el drama áureo: Los blasones de los Austrias en Calderón y Bances Candamo», en La teatralización de la historia en el Siglo de Oro Español. Actas del III Coloquio del Aula Biblioteca «Mira de Amescua» celebrado en Granada del 5 al 7 de noviembre de 1999 y cuatro estudios clásicos sobre el tema, ed. R. Castilla y M. González Denigra, Granada, Universidad, 2001, pp. 569-590.

Calderón de la Barca, P. La gran Cenobia, Dramas, tomo I, Madrid, Aguilar, 1966.

Cigüeña Beccaría, M. D., «De la comedia Hero y Leandro de Mira de Amescua, y algunas obras dramáticas de Calderón», Boletín de la Real Academia Española, 69, 1989, pp. 465-491.

Díez Borque, J. M., Sociología de la comedia española del siglo XVII, Cátedra, Madrid, 1976.

Farinelli, A., «Mistici, teologi, poeti e sognatori della Spagna all'alba del dramma di Calderón», Revista de Filología Española, 4, 1914, pp. 289333.

\footnotetext{
${ }^{23}$ Villanueva, 2001, pp. 247-278, passim p. 260.
} 
González Ruiz, N., Piezas maestras del teatro teológico español, BAC, Madrid, 1946, 2 vols. (usamos la reimpresión de 1996).

José Prades, J. de, Teoría sobre los personajes de la Comedia Nueva, Madrid, Consejo Superior de Investigaciones Científicas, 1963.

Kennedy, R. L., "Tirso's La república al revés. Its Debt to Mira's La rueda de la Fortuna, Its Date of Composition, and Its Importance», Reflexion, Ottawa, 2. 2-4, 1973, pp. 39-50.

- «La perspectiva política de Tirso en Privar contra su gusto, de 1621, y la de sus comedias políticas posteriores», en Homenaje a Tirso, Revista Estudios, 1981, pp. 199-238.

- Estudios sobre Tirso I. El dramaturgo y sus competidores (1620-1626), Revista Estudios, Madrid, 1983.

Mira de Amescua, A., La rueda de la Fortuna / La hija de Carlos Quinto, Madrid, Instituto de Estudios Madrileños, 2004.

Vega, L. de, Los Tellos de Meneses, Dramas, tomo I, Madrid, Aguilar, 1932 pp. 407-440.

Villanueva, J. M., El teatro teológico de Mira de Amescua, BAC, Madrid, 2001.

- "En esta vida todo es verdad y todo mentira, de Calderón de la Barca», en Actas del IV Centenario del nacimiento de don Pedro Calderón de la Barca, ed. M. Abad Varela, Madrid, UNED, 2004, pp. 245-256.

Wilson, M., Spanish Drama of the Golden Age, Oxford/London/Edinburgh, Pergamon Press, 1969.

\section{Apéndice}

Resumen de La rueda de la Fortuna

Acto I. Filipo, capitán del emperador Mauricio, vuelve victorioso de los eslavonios. El emperador le promete laureles inmortales. La infanta le reitera el amor que le entregó al marchar. En contraposición, el capitán general Leoncio, vuelve derrotado por primera vez, después de incontables victorias. El emperador lo degrada dando su cargo a Filipo y lo injuria, arrojándolo al pueblo con una rueca para que todos se burlen de él. Leoncio ha traído a Mitilene, hermosa mujer a la que apresó en la tienda real de los persas. De ella se enamoran el emperador, el príncipe Teodosio y Filipo. Los tres cometerán abusos por su pasión. Frente al marido, la emperatriz Aureliana es bondadosa y limosnera. Y, hablando con Heracliano, noble retirado a las cercanías de Constantinopla, desvela que su hijo verdadero es Heraclio, el niño enviado a Heracliano recién nacido, por unos sueños terribles que auguraban desgracias para toda su 
familia; condicionada por ellos, suplantó al príncipe por el hijo de unos esclavos. Los excesos del príncipe, que llega a dar un bofetón a «su» madre, fuerzan a la emperatriz a enviar a Mitilene a las montañas con Heracliano y Heraclio.

Acto II. La Infanta Teodolinda y la Emperatriz reprochan olvido y excesos, a Filipo y al príncipe, respectivamente. Entra el emperador, que arrastra de los cabellos a la emperatriz por haber alejado a Mitilene; niega la ayuda solicitada por el papa, y menosprecia los consejos de su mujer. Avisos extraños anuncian que el emperador morirá pronto a manos de Focas. Aquel ordena a Filipo buscar a este villano «bajo de cuerpo y moreno». En el monte comienzan los amores de Heraclio y Mitilene, la cual, tras una reveladora conversación con el joven, se queda dormida. Leoncio, al verla, se vence a sí mismo y se esconde. El príncipe pretende abusar de la joven, pero «voces del cielo", de Leoncio, la salvan. Entra Filipo buscando a Focas; descubre a Mitilene; tras intensa lucha interior, vence el respeto. Leoncio pide limosna a Filipo, que se la concede. Y, a Mitilene, que le da una sortija por haberla ayudado ante el príncipe, le anuncia que reclamará su derecho cuando recobre el honor perdido. A continuación, salen Heraclio, Heracliano y los músicos; Mitilene descubre que es hija bastarda del rey de Persia. Al conocer su cuna, Heraclio se va a buscar gloria suficiente para merecer su amor. En palacio el emperador pide perdón a la emperatriz por sus culpas pasadas. Filipo llega con Focas; pero el emperador lo deja libre porque sería injusto matarlo, ya que es inocente.

Acto III. El ejército se amotina. Elige a Leoncio, que se autorrestituye el bastón de general, pero renuncia al imperio. Mientras discuten, un águila deja una espada con el lema: «Tenla y reina solo un día. Capitanes y soldados no consiguen desenvainarla; pero sí Focas, que vuela al palacio con el ejército menos Leoncio. El emperador, antes de morir a manos de Focas, sin que Filipo pueda evitarlo, maldice al príncipe, reconoce a Heraclio como hijo suyo y hace que se salven la emperatriz y la infanta. Ya en el campo, Filipo debe pedir limosna para alimentarlas. Leoncio, después de dársela, lo pone a prueba: salvar a dos de las tres mujeres. Tras otra lucha interior, se decide por la emperatriz y la infanta, excusándose ante Mitilene. Cosroes, hermano de esta, llega ofreciendo riquezas sin cuento por la princesa, la cual reconoce al príncipe. Unos soldados persiguen a Heraclio por haber matado a Focas. Las súplicas de la emperatriz y los 
cielos, con voces, consiguen que Leoncio lo proclame emperador. Heraclio se casa con Mitilene tras la renuncia de Leoncio que la pide en matrimonio como pago de su deuda, y Filipo se casa con la infanta.

Resumen de Lagran Cenobia

Jornada primera.- Aureliano sueña, dormido y despierto, que será emperador de Roma. Inspirada por el oráculo de Apolo, acompañada por el ejército, Astrea llega hasta él para proclamarlo emperador de Roma. Nada más aceptar el imperio, establece como palacio el monte y promete no entrar en Roma hasta lograr muchas victorias. Anuncian la llegada del invicto general Decio, el cual, con armas negras, regresa vencido de Cenobia. Aureliano escucha sus disculpas, tachándolo de cobarde. El vencido declara haberlo sido por la fuerza - era como una Palas - y la hermosura - descripción maravillosa de la reina-. Soberbio, el nuevo César se burla del general por haber sido vencido por una mujer, contestándole Decio que también a él lo hubiera vencido, pues, aunque denoste a la fortuna, puede tornarse contra él. Menospreciándolo, el emperador le quita la espada y asegura que su primera victoria será Cenobia. Decio lo maldice. En Palmira, Libio aconseja a Irene matar a Abdenato, esposo de Cenobia, pues, después, el pueblo lo nombrará rey. Cenobia administra justicia; sospecha de Libio, pero confia en Irene. El cobarde Persio presenta a Cenobia los papeles «testimonio" de un soldado muerto, Andronio. Ante la reina, esta queda prendada de su valor y lo toma como guarda de su persona. Disfrazado, llega Decio; le declara haber sido vencido por el amor y la hermosura; le comunica la inmediata llegada de Aureliano para que se prepare. Para mantener su honor, también defendido por Cenobia, el exgeneral regresa a luchar con los suyos; pero lleva una banda que ella entrega como señal, aunque le dice que él la tenga como quiera (como «favor»).

Jornada segunda.- Irene y Libio lamentan el fracaso de su intento, pues, a pesar de haber envenenado a Abdenato, el pueblo ha aclamado a Cenobia, que ha rechazado dos veces a Aureliano. Al quejoso traidor, le asegura que confia en su espada para la victoria. Antes de recibir los refuerzos de Persia, Cenobia vuelve a salir contra Aureliano, el cual, confiado en el oráculo de Apolo, en palabras de Astrea: «Irás y vencerás; no / serás vencido en la guerra», es vencido de nuevo; Astrea le confiesa su errónea lectura-interpretación del oráculo: «Irás y vencerás 
no; / serás vencido en la guerra». Ofendido contra ella, la arroja en una cueva, desde la cual sus palabras se convierten en "voces del cielo» para Cenobia, Libio y Decio, quien, por fin, la libera y la recoge en su tienda. Hasta él llega Aureliano, declarándose vencido de la reina de Palmira; oculto por la banda de ésta, Decio le ofrece su ayuda, jurando defenderlo hasta la muerte; él le da su bastón para "compensarle» en su momento. Llegan Cenobia y unos soldados. Tras reconocerlo la reina, ordena a los soldados alejarse. Ya solos, fieles a sus promesas, están dispuestos a pelear hasta la muerte; mutuamente se preguntan qué harían en lugar del contrario; el resultado es que la reina renuncia a la victoria. Hasta Aureliano llega Libio; le ofrece, con cien soldados, apresar a la reina; él le da su anillo. Esta, presa, solo ruega a Aureliano la libertad de su patria. Venciendo, incluso, su tendencia amorosa, el Emperador ordena despeñar a Libio, después de darle su corona. Irene acudirá a salvarlo, con el anillo.

Jornada tercera.- Decio describe a Astrea la entrada triunfal de Aureliano en Roma, con Cenobia presa; el general lamenta «que sus fortunas tengan / él un leal que la guarde / y ella un traidor que la venda». Sin hacer oídos, Aureliano aumenta su soberbia. Para ofender más a Decio, que le reclama su pago-premio, ordena, sin atenderlo, proseguir el «triunfo». Decio determina matarlo; con él se conjura Astrea, ofreciéndole sus manos. Lo mismo deciden Libio e Irene. Cenobia llega a Aureliano, simulando amor, para vencer al soberbio; pero recibe desprecios - testigo oculto Decio-, quien, nada más ausentarse el tirano, le reprocha su comportamiento a la amada, que, para satisfacerlo sin declararse, asegura que ni conoce amor ni celos. El amante sí está celoso y decide matar a su enemigo, más que por honor, por celos. Astrea le comunica la ocasión propicia, pues da audiencia; la abraza, agradecido, siendo visto por Cenobia; el general, en cuanto queda solo, recibe los reproches y las quejas de la reina - consciente ya de que son celos-, por abrazar a otra mujer. Se prometen su amor. En la audiencia, soberbia e injusticia rigen los actos del emperador; se gana la enemistad de todos. Mientras Irene le habla, Libio intenta apuñalarlo; el temor se lo impide. Tras llegar Astrea, cada uno por un sitio se acercan al emperador; él despierta y los considera fantasmas. Así que Decio, a solas, cumple su venganza. Espera que los soldados lo maten; en su lugar, lo nombran emperador; y ordena ajusticiar a Irene y Libio - se confiesan asesinos de Abdenato-, a pesar de las súplicas de Cenobia. 